\title{
Fetishism and narcissism - the base of capitalism?
}

\author{
Anselm Jappe \\ Accademia di Belle Arti di Sassari, Sassari, Italy \\ anselm.jappe@accademiasironi.it \\ Recibido: 17 de noviembre de 2019 | Aprobado: 9 de marzo de 2020 \\ https://doi.org/10.17533/udea.ef.n62a09
}

Abstract: This article tries to resume Karl Marx' concept of "commodity fetishism", not just as a phenomenon of conscience, but as being the real heart of capitalist society based on abstract labor and value, money and commodity. This concept is often misunderstood, as well as the concept of "narcissism". Following Freud and Christopher Lasch, the article underlines the sociological side of narcissism and how this pathology is the psychological counterpart to commodity fetishism, forming thus the typical subjectivity of consumerism.

Keywords: commodity fetishism, narcissism, Marxism, capitalism, consumerism

Cómo citar este artículo:

Jappe, A. (2020). Fetishism and narcissism -the base of capitalism? Estudios de Filosofía, 62, 165-173. https://doi.org/10.17533/udea.ef.n62a09 


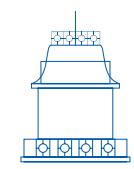

ARTÍCULOS

DE REFLEXIÓN

\section{Fetichismo y narcisismo ¿la base del capitalismo?}

Resumen: Este artículo intenta retomar el concepto de Karl Marx de "fetichismo de los productos básicos" no solo como un fenómeno de la conciencia, sino como el verdadero corazón de la sociedad capitalista basada en el trabajo, el valor abstractos, el dinero y los productos básicos. Este concepto es a menudo mal entendido, así como el concepto de "narcisismo". Siguiendo a Freud y Christopher Lasch, el artículo presenta el lado sociológico del narcisismo y cómo esta patología es la contraparte psicológica del fetichismo mercantil, formando así la subjetividad típica del consumismo.

Palabras clave: fetichismo de los productos básicos, narcisismo, marxismo, capitalismo, consumismo

\section{Anselm Jappe}

is the author of Guy Debord (1993, University of California Press; 1999, PM Press, 2016; in Spanish, Anagrama, 1998), Les Aventures de la marchandise. Pour une nouvelle critique de la valeur (Denoel 2003; in Spanish, Pepitas de Calabaza, 2016), L'Avant-garde inacceptable. Réflexions sur Guy Debord (Lignes, 2004), Crédit à mort (Lignes 2011, translated as The Writing on the Wall, Zero Books, 2016; in Spanish, Pepitas de Calabaza, 2011), La Société autophage. Capitalisme, démesure et autodestruction (La Découverte, 2017; in Spanish, Pepitas de Calabaza, 2019). He contributed to the German magazines Krisis and Exit !, founded by Robert Kurz, which developed the "critique of value". He teaches at present at the Fine Art Schools of Sassari (Italy) and has been visiting professor in various European and Latin American universities. He also lectured at the Collège international de philosophie (Paris). 
"Fetishism" and "narcissism" are two terms that are often heard in everyday speeches, especially in recent times. At first glance, their meaning seems very clear. Narcissism is the attitude of whose who constantly look at themselves in the mirror and exalt their external appearance, and more generally indicates a selfish person, too convinced of his or her merits, who wants to make the world, and especially other peoples' life, turn around them. The narcissist then becomes a danger in the workplace, especially if he is the boss, and it is a great disgrace to have him as a partner in a relationship. According to a current statement, social networks have strongly increased narcissistic tendencies in society.

Fetishism, on the other hand, indicates a kind of love that is considered excessive for something (an object, a behaviour, a person). So we can find, for example, a fetishist of Rossini's music, or, with reference to sexual fetishism of which Sigmund Freud speaks, a man who gets excited seeing high heels or leather cloths. Often reference is also made to the "commodity fetishism" introduced by Karl Marx into the debate, and is then referred, normally to condemn them, to those who dot on big cars or for a brand of clothes whose consumption, it is suspected, must hide the poverty of their lives.

These uses of the words fetishism and narcissism are not "wrong": they cover real phenomena that are encountered every day. And the question is not whether these use of the words remains faithful to the original definitions given by Freud, Marx or, in the case of fetishism, also by the history of religions and anthropology. It is not a philological issue. The question is here to know if these two concepts will allow a wider and deeper understanding of the heart of contemporary society -an understanding that would derive from a renewed reading of Marx' and Freud's original concepts, without however always focusing on their letter. The fetishism of the commodity is introduced by Marx at the end of the first chapter of Capital (1867/1976), after having analyzed the basic categories of the commodity-producing society, and therefore of capitalism: the abstract side of labour, called abstract labour, i.e. labour considered as the simple expenditure of undifferentiated human energy, measured in time, which forms the value of the (material or immaterial) commodities and is finally represented in money. Marx describes commodity fetishism as a social relationship between things and a relationship of things between people, expression of a way of production where production directs humans instead of humans directing production. Men relate their private works not directly, but only in an objectified form, under the appearance of things, that is, as a determined quantity of equal human labour, expressed in the value of a commodity. However, they are not aware of doing so and attribute the movements of their products -the exchanges between producers and the proportions in which they exchange commodities - to the natural qualities of the latter. Fetishism is an unconscious and collective process that hides the true nature of capitalist production. Marx himself describes it as "mysterious" and uses formulas according to which the commodity is "sensible-suprasensible" and is comparable to religion where man projects his forces on a transcendent being from which he then believes to depend. 
Marx terms commodities "sensuous things which are at the same time 'suprasensible or social"', since the relationships between men appear there as things, and things appear as creatures endowed with their own will (Marx, 1976, p. 165). It is better to reproduce the most important passages than to summarise:

The mysterious character of the commodity-form consists therefore simply in the fact that the commodity reflects the social characteristics of men's own labour as the objective characteristics of the products of labour themselves, as the socio-natural properties of these things. Hence it also reflects the social relation of the producers to the sum total of labour as a social relation between objects, a relation which exists apart from and outside the producers. Through this substitution, the products of labour become commodities, sensuous things which are at the same time suprasensible or social. (...) It is nothing but the definite social relation between men themselves which assumes here, for them, the fantastic form of a relation between things. In order, therefore, to find an analogy we must take flight into the misty realm of religion. There the products of the human brain appear as autonomous figures endowed with a life of their own, which enter into relations both with each other and with the human race. So it is in the world of commodities with the products of men's hands. I call this the fetishism which attaches itself to the products of labour as soon as they are produced as commodities, and is therefore inseparable from the production of commodities. (...) To the producers, therefore, the social relations between their private labours appear as what they are, i.e. they do not appear as direct social relations between persons in their work, but rather as material (sachlich) relations between persons and social relations between things (Marx, 1976, pp. 164-166).

As a result, in commodity production, "the process of production has the mastery over man, instead of the opposite" (Marx, 1976, p. 175) and for the producers, "their own movement within society has for them the form of a movement made by things, and these things, far from being under their control, in fact control them" (Marx, 1976, pp. 167 s.). The fetishism is already present in the very fact that social activity takes the form of the commodity, value and money, the "semblance of objectivity possessed by the social characteristics of labour" (Marx, 1976, p. 167). Men are, however, not conscious of this appearance. They produce it without knowing it through acts of exchange in which, like a natural law, socially necessary labour time imposes itself as a regulatory element. It is the money form that makes the real relationship between commodities disappear behind a thing-like appearance: the visible fact that a shirt is worth ten dollars is only a thing-like expression of the relationship between quantities of abstract time, thus, productive activity is reduced to a simple "productive expenditure of human brains, nerves, muscles" (Marx, 1976, p. 134). In other words, one initial meaning of the term "fetishism" is the following: men do not bring their private labours into relation directly, but only in an objective form, with the appearance of a thing, 
namely, equal human labour expressed in a use value. Nevertheless, they do not do so in a conscious manner. They attribute the movement of their own products to the natural qualities of these products.

However, "the whole mystery of commodities, all the magic and necromancy that surrounds the products of labour on the basis of commodity production" applies to commodity society alone (Marx, 1976, p. 169). Marx shows that in autarkic, or selfsufficient, production (he uses the example of Robinson Crusoe), such as one finds in medieval society or, on the contrary, in a "free association of producers", there is no fetishism, and social relationships are not "disguised as social relations between things, between the products of labour" (Marx, 1976, p. 170). On the contrary, "for a society of commodity producers (...) general social relation(s) of production (consist) in the fact they treat their products as commodities, hence as values, and in this material (sachlich) form bring their individual, private labours, into relation with each other as homogenous human labour" (Marx, 1976, p. 172). Marx continues to evoke fetishism in the following chapter, "The Process of Exchange", which concludes:

Men are henceforth related to each other in their social process of production in a purely atomistic way. Their own relations of production therefore assume a material shape which is independent of their control and their conscious individual action. This situation is manifested first by the fact that the products of men's labour universally take on the form of commodities. The riddle of the money fetish is therefore the riddle of the commodity fetish, now become visible and dazzling to our eyes (Marx, 1976, p. 187).

However, it is the first lines of the second chapter of Capital that provide the best definition of the essence of fetishism, even if the word itself does not appear: "Commodities cannot themselves go to market and perform exchanges in their own right. We must, therefore, have recourse to their guardians, who are the possessors of commodities" (Marx, 1976, p. 178). It is the commodities themselves which are the real actors -the "subject"- in a commodity society. Human beings only enter onto the stage as the servants of these objects, as a necessary evil for production and circulation.

These pages of Marx - which also have echoes in some other passages of his works- have either been neglected by most of Marx's interpreters or have been understood as the denunciation of a mystification that perpetually takes place in capitalist society: fetishism naturalizes - that means, it falsely presents as natural- the conditions of exploitation and theft of surplus labour (and therefore of surplus value) to the detriment of the workers, theft that characterizes capitalism. This disguise of capitalist reality obviously exists. Marx speaks about it at the end of the third volume of Capital, in a chapter entitled, in yet another reference to religion, "The Trinity Formula" (which forms part of the section "The Revenues and their Sources"). In this chapter, Marx analyses the fact that the three principal factors of production -capital, land and labour- appear, in the eyes of economic actors, as factors that contribute 
to wealth creation, which would justify the pretentions of capitalists and property owners to receive a part of the surplus value realised as "just" compensation for the production factor that they contributed. Bourgeois political economy sought, and still seeks, to give a theoretical foundation to this sharing out that does indeed dominate in capitalist society. At a material level, these three factors are obviously necessary for production. However, the false appearance that dominates the consciousness of subjects in capitalist society -and a little later Marx speaks of a "religion of everyday life"- identifies the material and technical factors of production with their social form and attribute to the different material factors of labour the capacity to produce the value of the commodity. The denial that labour is the only source of value (and therefore of surplus value) is essential for the apologists of capitalism because they hope to show that there is no "injustice" in the way that workers are paid. Bourgeois political economy, and the spontaneous representations of the ruling classes that it systematises, therefore operates a "mystification" of consciousness by confusing things - the material agents of production-with social relationships: "This formula also corresponds to the self-interest of the dominant classes, since it preaches the natural necessity and perpetual justification of their sources of income and erects this into a dogma" (Marx, 1991, p. 969).

Traditional Marxism identified the problem of fetishism with the ideological side of the phenomenon, belonging to the sphere of consciousness, or even with a conscious cheat on the part of bourgeois economists which serves to veil the everyday reality of exploitation. But fetishism in the original Marxian sense goes much further, as we hope to show. The strength of Marx's concept is that of exposing the real reversal that occurs in capitalism.

In capitalism, the abstract side of the work (expenditure of labour as pure quantity and without regard to the content) prevails over its concrete side, the commodity value prevails over use value. What counts is only the amount of labour done and the part of surplus-labour it contains, since this is translated into value, into surplus value and finally into profit. What is produced by this labour is secondary or irrelevant. Only its quantitative growth, its accumulation, counts.

If you produce bombs or wheat matters very little in terms of value: more bombs and less wheat will be produced if the bombs contain more surplus value. The concrete side of commodities - whether they are material goods or services makes no differencebecomes subordinate, is a mere bearer for the only thing that matters in a capitalist economy: the amount of value. The concrete side, which is the one that corresponds to human needs and desires and should constitute the purpose of production, is instead reduced in the commodity society to depend on what actually derives from it: its abstract representation.

This is not an illusion or a staging, but the deepest, and very real, level of capitalist logic. While exploitation and class division are also found in many other societies, this inversion between abstract and concrete is a hallmark of capitalism alone. However, 
it is not an "abstract" or secondary phenomenon: it explains the destructive and blind nature of capitalist society and also constitutes the real root of the devastation of the natural foundations of life by the economy (Jappe, 2017a).

This reading of fetishism has gained much ground in recent decades and has largely replaced the more problematic concepts of "alienation" (of the young Marx) and of "reification" (Lukács, 1983). But what link can be established with the concept of narcissism? It was introduced by Freud starting in 1910. ${ }^{1}$ Narcissism essentially consists of an indistinction between the self and the surrounding world and in the tendency to perceive the external world -the "objects" in the broad sense, including people- only as projections and extensions of the self. It is a necessary phase in the psychic development of the very young child who defends himself from the painful perception of his real impotence by creating a feeling of fusion between himself and the world that leads to feelings of omnipotence. What is problematic is the "secondary narcissism" of the adult who has not really overcome the narcissistic phase, overcoming which normally occurs with the Oedipus complex after which the child abandons his fantasies of omnipotence to replace them with limited, but real satisfactions. But since this renunciation is painful, more or less strong unconscious traces of the original narcissism can continue in adult life and take on pathological traits. The narcissist is not intimately convinced of the real presence of an external world with which he has to deal with, but tries to put everything and everyone in his service. The importance of pathological narcissism is however limited in Freud's work, which is essentially aimed at the study of neuroses. Starting from the seventies of the twentieth century, its importance in the discourse of psychoanalysts and psychiatrists, which now very often have to do with people suffering from narcissistic disorders, has increased greatly. But it was the American Christopher Lasch who introduced narcissism into the sociological and political discourse with his books The Culture of Narcissism (1979) and The Minimal Self (1984). According to him, contemporary culture is deeply marked by narcissism. Above all, fusion and omnipotence fantasies are found in phenomena so different as the use of technology and the New Age, the lack of interest in politics or in minimalist art. Narcissism is therefore not limited to single pathological individuals, but also impregnates collective choices.

However, Lasch has little to say about the causes of this epochal change. The need therefore arises to combine his concept of narcissism, whose fertility seems undoubted, and a critique of contemporary capitalism centered on the concepts of value, abstract work and fetishism of the commodity.

The increase in the "rate of narcissism" during the twentieth century could be linked to the spread of the value and commodity logic in all the pores of society. This logic, with its inversion of the concrete and the abstract, has long since outgrown the

1 The main essay On Narcissism: an introduction dates from 1914. 
boundaries of commodity production alone to invade and colonize all spheres of life, especially consumption and interpersonal relationships. The changes in the psyche of individuals are at the same time the cause and the consequence of the evolution in the productive sphere which it would be very reductive to call only "economy": the inversion between abstract and concrete is a basic structure that pervades, in many forms, all modern society and whose origins can be traced back to Descartes in the XVII century. There is no priority between "objective" and "subjective" factors, between "base" and "superstructure", between "material production" and "consciousness". The classical neurosis, which predominated in the times of Freud, was the consequence of the renunciations imposed on individuals who were obliged to direct their libidinal and aggressive energies towards productive work. From the sixties on, the epicentre of social life has (apparently) shifted towards consumption. The injunction given to individuals was no longer: "Work, save, sacrifice, obey" (as an extension of the "Churches" "Ora et labora"), but "Consume, have fun, spend, get into debt". Instead of constantly reminding the subjects of their limits and their dependence on higher instances (state, religion, morals, social hierarchies), they are encouraged to overcome all limits (at least in their imagination) and to believe that the world is at their disposal: which is of course a lie, but it allows us to push on to a continuous consumption of commodities and images that at least give the impression that this is the case. The more the consumer believes that he can get "everything" in life -and the advertising reminds him at least a hundred times a day -the more he is willing to work like a fool and to get into debt to buy his drugs (literally and metaphorically). And therefore to run the ever more fatigued machine of capitalist reproduction.

There is also an even deeper level of the link between narcissism and fetishism. Narcissism consists in a devaluation of the world outside the subject: all objects are nothing but projections of the subject and do not have a reality of their own, an autonomy to be respected. The narcissistic subject, however, is empty on his part, because he has never enriched himself in relations with external objects and has rather remained a prisoner of his fantasies. A narcissistic individual is not at all strong, as one might believe, but weak, because he is "wordless". Now, this wordlessness, this denial of the diversified qualities of the real in favour of a single equal substance (the Ego), which for its part is devoid of quality and is abstract, is what characterizes narcissism -but characterizes equally the logic of value and abstract labour. For the logic of value, the whole world consists only of portions of quantities lacking intrinsic quality, that is, of goods that are distinguished only by the amount of abstract labour they contain. It is a devaluation, an emptying of the concrete- the multiplicity of the existent is reduced to consist only of pieces of an abstract substance that is always the same (the value). For the narcissist, the world of non-I loses its autonomous reality; for the fetishist logic of the commodity, the world outside the accumulation of abstract unity of work is only a shadow (Jappe, 2017b). That is why fetishism and narcissism are now intertwined. For our greatest misfortune. 


\section{References}

Freud, S. (1957). On narcissism: An introduction. In J. Strachey (Ed. \& Trans.), The standard edition of the complete psychological works of Sigmund Freud (Vol. 14, pp. 73-102). London: Hogarth Press.

Jappe, A. (2017a). Les Aventures de la marchandise. Pour une critique de la valeur. Paris: La Découverte.

Jappe, A. (2017b). La Société autophage. Capitalisme, démesure et autodestruction. Paris: La Découverte.

Lasch, C. (1979). The Culture of Narcissism: American Life in an Age of Diminishing Expectations. New York: Norton.

Lasch, C. (1984). The Minimal Self: Psychic Survival in Troubled Times. New York: Norton.

Lukács, G. (1983). History and Class Consciousness.London: Merlin Press.

Marx, K. (1976). Capital: A Critique of Political Economy, vol. 1. (B. Fowkes, Trad.). London: Penguin.

Marx, K. (1991). Capital, vol. 3. (D. Fernbach, Trad.). London: Penguin. 